\title{
In re Leasing Consultants, Inc.: The Double Perfection Rule for Security Assignments of True Leases
}

In re Leasing Consultants, Inc., ${ }^{1}$ decided by the Second Circuit in 1973 , is a case of first impression involving assignments of equipment leases under Article 9 of the Uniform Commercial Code.2 Equipment lease financing typically involves two transactions: ${ }^{3}$ (l) the lessor signs a lease with a lessee; and (2) the lessor assigns a security interest ${ }^{*}$ in the right to receive rental payments and in the right to repossess the leased equipment as collateral for a loan from a third party financer. Under the Code, the secured transactions aspects of the first step can follow an established pre-Code pattern. ${ }^{5}$ But since the equipment lease has only recently become a major commercial financing device, ${ }^{B}$ the relevant Code provisions were drafted without particular attention to

1. 351 F. Supp. 1390 (E.D.N.Y. 1972), remanded for coidentiary hearing, 486 F.2d 367 (2d Cir. 1973). Accord, Feldman v. First Nat'l City Bank, 368 F. Supp. 1333, 1339-40) (S.D.N.Y. 1974) (litigation involving same parties, but different lease).

2. Hereinafter cited as the UCC or the Code or by section number only. Unless otherwise indicated, all references are to both the 1962 and 1972 versions of the Code. In both New York and New Jersey (the states involved in Leasing Consultants), as well as in 37 other states, the 1962 version is still in force. Some 12 states have enacted the 1972 version of the Code. Only Louisiana has not enacted the Code at all. UCC REr. SERV., art. 9, app. at 2 (1975); 4 CCH SEC. Traxs., Installment Credit Guide, No. 162, at 1 (1975) (Kansas).

3. See generally sources cited in note 6 infra.

4. A security interest is "an interest in personal property or fixtures which secures payment or performance of an obligation." $\$ 1-201(37)$.

5. See Coogan, Leases of Equipment and Some Other Unconventional Security Dc. vices: An Analysis of UCC Section 1-201(37) and Article 9, 1973 DuKE L.J. 909, 936.

6. See Shapiro, The $A B C^{\prime}$ 's of Leasing, in EQUIPMENT LEASING IN THE 1970 's 11 (S. Shapiro \& A. Reisman eds. PLI Commercial Ser. No. 95, 1973); Weiss \& McGugan, The Equipment Leasing Industry and the Emerging Role of Banking Organizations, NEw ENG. Econ. REv, Nov.-Dec. 1973, at 3. This new development is motivated primarily by the tax advantages of the equipment leasing transaction. Under provisions of the foderal income tax law's effective in 1962, a corporation which purchases certain types of depreciable equipment can obtain a tax credit for the year of purchase. INT. REv. CODE of 1954 , $\$ \$ 38-48$. However, a corporation cannot use these credits to reduce its tax liability by more than 50 percent in one year. As a result,

many corporations have adopted lease financing to, in effect, split the benefits of that portion of the investment credit (and depreciation deductions) which they cannot otherwise use to the maximum benefit with an earnings rich corporation or a group of high tax bracket individuals, generally referred to as the cquity owners, willing to acquire the necessary capital equipment and lease it to the corporation at a rental set below the normal rate to reflect the tax benefits obtained by the equity owners.

Riordan \& Duffy, Lease Financing: A Discussion of Security and Other Considerations from the Institutional Lenders' Point of View, 24 Bus. LAw. 763 (1969). 
the problems involved at the subsequent assignment step. ${ }^{\top}$ Faced with a novel problem at this step, the Second Circuit in Leasing Consultants imposed differing burdens on a financing assignee seeking to protect its interest in the leased equipment, depending on whether the underlying agreement is characterized as a "true lease" or a "security lease." The court's approach should be rejected.

\section{The Problem: Perfection of Security Interests in Equipment Lease Financing}

\section{A. The Lessor-Lessee Relationship: True Leases and Security Leases}

In $\$ 1-201(37)$, the Code recognizes two theoretically distinct types of agreements written in lease form-true leases and security leases. ${ }^{8}$ The true lease is what is commonly meant by the word "lease." In theory, the lessor allows the lessee to use the equipment for some fraction of its useful life, but "fully expects to retake the chattel at the end of the lease term and either resell or re-lease it." 9 The right to possession of the equipment upon default or expiration of the lease may be termed the "equipment reversion."10

The security lease may be thought of as a "disguised" security agreement, ${ }^{11}$ a secured installment sales contract,"12 or a lease "intended as security." 13 Although the security leasing agreement is written in lease form, the security lessor does not expect to retake the goods at the end of the lease period but instead to transfer full ownership to the "lessee" for a minimal sum. ${ }^{14}$ For this reason, the Code treats security leases as security agreements, giving the "Iessor" a security interest in the "leased" property.

Under the Code, the holder of a security interest must generally

7. Professor Gilmore, one of the Code's chief draftsmen, has written that "the newfangled equipment leases did not come under judicial scrutiny before the widespread enactment of Article 9 of the Code." 1 G. Gilmore, SEcurity INTERests in Personal Property \$ 3.6, at 81 [hereinafter cited as GILMORE].

8. See generally J. White \& R. Summers, THE Uniform Commercial Code $\$ 22-3$ (1972) [hereinafter cited as WHITE \& SUMMERs]. For the origins of the distinction between true and security leases, see p. 1731 infra.

9. Comment, Equipment Leasing Under the UCC, 13 U.C.L.A.L. REv. 125, 134 (1965).

10. Cf. Restatement of:Property $\$ \$ 154-55$ (1936).

11. A security agreement is "an agreement which creates or provides for a security interest . . ." \$9-105(1)(h) (1962 version); $\$ 9-105(1)(l)$ (1972 version). For the definition of a security interest, see note 4 supra.

12. WhItE \& SuMMers, supra note $8, \S 22-3$, at 762.

13. \$ $1-201(37)$.

14. Clark, Bankers Guide to UCC Filing Problems-Loans for Equipment Leasing, 92 BANkinc L.J. 222, 224-26 (1975). Under a typical security agreement, the debtor acquires full ownership as soon as the required payments are completed. 
protect or "perfect" 15 the interest against third parties by filing in the appropriate recordkeeping office. ${ }^{18}$ The purpose of this filing is to give notice of the security interest to third parties who might otherwise deal with the grantor of the security interest in the mistaken belief that the grantor owned the collateral outright rather than subject to the security interest. ${ }^{17}$ An unfiled or unperfected security interest, including one created by a security lease, is voidable by the debtor's trustee in bankruptcy. ${ }^{18} \mathrm{~A}$ true lease does not create a security interest and hence is not subject to filing requirements; the true lessor may repossess the equipment upon default or expiration of the lease without fear of losing the equipment to the lessee's trustee in bankruptcy. ${ }^{10}$

15. WhITE \& SUMMERS, supra note $8, \S 23-5$, at 796:

Perfection is a term of art in Article Nine . . . The legal consequences of perfection are considerable. Indeed, the perfected secured creditor is nearly as far above the unperfected secured creditor on the pecking order as the unperfected secured creditor is above the general creditor.

16. Id. at 796-97:

By far the most common and most important method of perfection of a security interest under Article Nine is the filing of a financing statement . . . . A seconcl method of perfection which may be used with respect to certain kinds of collateral [e.g., goods, id. \$23-10; UCC $\$ 9.305]$ and which must be used with respect to some kinds of collateral [e.g., negotiable instruments, WHITE \& Summers $\$ 23-10$, at 815; UCC $\S 9-304(1)$ ] is creditor possession of the collateral-the pledge. Finally, some security interests $[e . g$., in consumer goods, WHITE \& SUMMrRs $\$ 23-5$, at 797; UCC $\$ 9-302(1)(d)]$ are automatically perfected under the Code at the time of their creation and without the performance of any additional act by the secured creditor.

This Note assumes that only one filing in a juxisdiction is sufficient to perfect a security interest. Multiple filings may in fact be required by state law. See Clark, supra note li, at 243. See generally WhITE \& Summers, supra note $8, \$ \$ 23-11,-12$.

17. White \& Summers, supra note $7, \S 23-5$, at $796-97$ :

[A] financing statement is a simple notice which contains only enough information to notify a reader that the creditor named claims an interest in certain categories of collateral belonging to the debtor named. The financing statement is not often the operative document which created the security interest between the parties but is merely a publicly filed notice which tells a reader where to hunt for more information.

See generally Levin, The Intention Fallacy in the Construction of Title Retaining Contracts, 24 Mich. L. Rev. 130, 131-43 (1925).

18. $\$ 9-301(1)(b),(3)$; see WHITE \& Summers, supra note $8, \$ 23-5$, at 796 :

The most crucial legal consequence of perfection is the priority it earns the secured party over a subsequent lien creditor. Of course, the lien creditor par excellence is the trustee in bankruptcy wielding his section $\% 0(\mathrm{c})$ rights [of priority over unperfected security interests, id. $\$ 24-31]$. Thus a secured party who perfects prior to bankruptcy is likely to have the right to snatch the collateral out of the trustee's hands, but an unperfected secured party will invariably have to eat from the general creditors' trough in bankruptcy.

A typical case is In re Oak Manufacturing, Inc., 6 UCC Rep. Serv. 1273 (S.D.N.X. 1969), in which a referee in bankruptcy held that an agreement which was written in lease form was actually a security lease and that the lessor had only a security interest in the leased goods. Because the lessor had failed to perfect its interest by filing, the interest was held to be void against the lessee's trustee in bankruptcy.

An unperfected security interest is also subordinate to the rights of certain other lien creditors, $\$ 9-301(1)$, and purchasers, $\$ 9-307$; however, the trustee in bankruptcy is the only competitor of the lessor or lessor's assignee with which this Note is concerned.

19. Article 9 permits the filing of true leases to protect the lessor if the document is subsequently shown to be a security lease. $\$ 9-408$ (1972 version). See Coogan, The New UCC Article 9, in Coogan, Hogan \& Vagts, Secured Transactions under THE UCC, 1 UCG Serv. \$ 3A.05[2] (1974). 


\section{B. The Lessor-Assignee Relationship: The Assignee's Security Interests in the Rental Payments and the Equipment Reversion}

Whether the lessor has a security interest in or a reversionary right to the equipment, that is, whether the lease is a security lease or true lease, the lessor commonly assigns to a financing assignee security interests both in the right to receive rental payments from the lessee and in the rights in the equipment. At this point, the assignee of the true or security lessor must perfect its security interests against the lessor for the same reason that the lessor must perfect its interest against a lessee under a security lease. ${ }^{20}$ Otherwise, the assignee's interests may be avoided by the lessor's trustee in bankruptcy. It is with the perfection rules applicable to the lessors' assignees that Leasing Consultants is concerned.

\section{The Double Perfection Rule of In re \\ Leasing Consultants, Inc.}

Leasing Consultants, Inc. (Leasing), a New York corporation, entered into eight leases of equipment with Plastimetrix, Inc. (Plastimetrix), a New Jersey corporation. The equipment was kept in the Plastimetrix plant in New Jersey. ${ }^{21}$ Leasing then assigned a security interest in the leases and the leased equipment to First National City Bank (FNCB). FNCB took possession of the leases and filed financing statements against Leasing in New York, but did not file against Leasing at the situs of the equipment in New Jersey. ${ }^{22}$ Six months later, Leasing and then Plastimetrix entered bankruptcy. FNCB and Leasing's trustee in bankruptcy began litigation over the proceeds of the sale of the leased equipment surrendered by Plastimetrix. ${ }^{23}$

Because of a stipulation between the parties, the district court assumed that the Leasing-Plastimetrix agreements were true leases rather than security leases. ${ }^{24}$ The district court stated that as a true lessor, Leasing had two interests in its transactions with Plastimetrix. Leas-

20. See pp. 1723-24 supra.

21. Leasing filed financing statements against Plastimetrix in New Jersey; the filings purported to be "for informational purposes only," because the leases were allegedly true leases. 351 F. Supp. at 1392; 486 F.2d at 369.

22. 351 F. Supp. at $1392 ; 486$ F.2d at 369 .

23. 351 F. Supp. at $1392 ; 486$ F.2d at 370 .

24. The parties had stipulated that "[a]t all times relevant hereto, [Leasing] owned the leased equipment, subject to the claims and interests of the Bank . . ." $351 \mathrm{~F}$. Supp. at 1392; $486 \mathrm{~F} .2 \mathrm{~d}$ at 372 . The district court used the term "conditional sales agreement" instead of "security lease" but the two are treated equivalently under the Code. See Coogan, supra note 5 , at 973 . (A conditional sales contract is a device by which the vendor sells goods but retains title as security. See id. at 937 .) 
ing's right to receive rental payments was embodied in the leases. Since FNCB had possessed and filed against the leases in New York, the bank's security interest in the rental payments was perfected. ${ }^{25}$ Leasing also had a reversionary interest in the equipment. Adopting the views expressed by Joseph Levie, ${ }^{26}$ the court reasoned that the reversionary interest in the equipment was not embodied in the leases because the reversion is an interest which a lessor retains in granting a lease. ${ }^{27}$ Consequently, FNCB's security interest in the equipment reversion could only be perfected by filing at the situs of the equipment. ${ }^{28}$ Since the bank had not filed at the situs in New Jersey, its unperfected security interest in the equipment was inferior in priority to the lessor's trustee in bankruptcy, ${ }^{29}$ to whom the court awarded the proceeds of the equipment sale.

On appeal, the Second Circuit agreed with the district court that an assignee of a true lease must file against the equipment to perfect its interest in an equipment reversion. ${ }^{30}$ But the court also held that the stipulation between the parties did not foreclose the "critical" issue of whether the Leasing-Plastimetrix agreements were true or security leases. ${ }^{31}$ If the agreements were security leases, Leasing had parted with ownership of the equipment and had then taken back security interests together with its right to receive rental payments from Plastimetrix. Since Leasing's security interests in the equipment would thus have been granted as a part of the leases rather than retained outside them, FNCB's possession of and filing against the leases would have perfected the bank's interest not only in the rental payments but also in the equipment. ${ }^{32}$ The court remanded the case for a determination of whether the Leasing-Plastimetrix agreements were true or security leases. ${ }^{33}$

25. 351 F. Supp. at 1393 .

26. Levie, Security Interests in Chattel Paper, 78 YALE L.J. 935, 939-42 (1969).

27. $351 \mathrm{~F}$. Supp. at 1393. Under both real and personal property law, a reversion is an interest outside the lease. United States v. Shafto, 246 F.2d 338, 341-42 (4th Cir. 1957); 1 H. TIFFANX, THE LAw of LANDLORD AND TENANT $\$ 146(\mathrm{~b})$, at 868 (1912); see genenally Restatement OF Property $\$ \$ 154-55$ (1936).

28. Professor Robert Charles Clark has summarized the "conceptual basis" for the court's decision:

The lessor grants a leasehold interest to the lessee; the reversionary rights are what he has left; the reversionary rights, being left over from what was carved out by the lease, do not arise "under" the lease; ... perfecting against the lease and against the reversionary rights are therefore conceptually separate....

Clark, supra note 14, at 237-38.

29. \$ $9-301(1)(b),(3)$.

30. 486 F.2d at 370-72, also citing Levic, stupra note 26, upon which the district court relied.

31. 486 F.2d at 372 . The court noted that the stipulation had been made before the parties were aware that the true lease-security lease distinction was crucial.

32. Id.

33. Id. at 374. The parties had stipulated that the proceeds of the equipment sale would be awarded in a lump sum. Accordingly, the district court chose not to consider 
The Second Circuit's approach requires the same actions to perfect a security interest in rental payments under both true and security leases: the assignee must possess or file against the lease. However, in the court's view, the different nature of the true and security lessors' interests in the underlying equipment requires the assignees of true and security lessors to take different steps to perfect their security interest in the equipment. The assignee of a security lessor does not have to take any additional steps beyond perfection against the lease itself; the assignee of a true lessor must make an additional filing at the situs of the equipment. Thus, the Leasing Consultants court imposed a single perfection rule on the assignees of security lessors and a double perfection rule on assignees of true lessors.

Neither the district court, the court of appeals, nor the litigants considered the possibility that the Code should be construed to provide that possession of or filing against a true lease perfects an interest not only in the rental payments but also in the equipment reversion. ${ }^{34}$ All seemed to accept a double perfection rule for true lease assignments and a single perfection rule for security lease assignments. ${ }^{35}$ This Note contends that both the technical provisions of the Code and its broader policy and purpose support a single perfection rule regardless of the label applied to the agreement between lessor and lessee. No filing

whethor part of the proceeds represented FNCB's perfected interest in the rental payments under the leases. 351 F. Supp. at 1394. The Second Circuit intimated that a part of the proceeds might represent FNCB's interest in the leases, but left the district court free to keep the fund intact. 486 F.2d at 374 .

Since Plastimetrix had defaulted, one would assume that the entire proceeds of the sale represented the interest in the equipment. The opinions suggest, but do not clearly articulate, two theories which might justify a partial award to the bank.

(1) In the agreement with Leasing's trustee in bankruptcy under which Plastimetrix sturrendered the equipment, the bank apparently gave up its right to sue Plastimetrix for unpaid rent in exchange for a partial interest in the sale proceeds. See $351 \mathrm{~F}$. Supp. at 1392; 486 F.2d at 370 .

(2) The bank argued that under the leasing agreements, Plastimetrix had promised not only to pay rent but also to allow Leasing to repossess and sell the equipment upon default, and to credit the proceeds of the sale to any unpaid rentals. Therefore, the bank contended, perfection of a security interest against the leasc also perfected a security interest in the equipment to the extent of any unpaid rentals. The Second Circuit left this issue open on remand. $486 \mathrm{~F} .2 \mathrm{~d}$ at $373-74$. This approach is a hybrid of double and single perfection rules. It is inconsistent both with the Second Circuit's theory that the entire equipment reversion is retained ontside the lease, and with the Code policy of uniformity which supports the single perfection rulc. See pp. 1730-31 infra.

34. FNCB also contended, unsuccessfully, that a reversionary interest in equipment should be regarded not as "goods" but as "an intangible interest sited at Leasing's domicile in New York," in which case the bank's New York filings would have perfected its interest in the reversions under $\$ 9$-I03(2) (1962 version) (now contained, in substantial part, in $\$ 9.103(3)$ (1972 version)). $486 \mathrm{~F} .2 \mathrm{~d}$ at $371-72$. This Note does not consider the bank's general intangibles argument.

35. Although the district court did not address the perfection issuc for security lease assignments, its general reliance on Levie, who supports a single perfection rule for such leases, indicates that the court probably would have accepted a single perfection rule if confronted with the issue. 351 F. Supp. at 1392-93; Levie, stipra note 26, at 940-41. 
at the situs of the equipment should be required from the assignee whether the underlying agreement is a true lease or a security lease.

\section{Perfection of Leasehold Assignments Under the Code}

The Leasing Consultants double perfection rule is based on the view that the security lessor "gives up" and then "takes back" an interest in the equipment, while the true lessor "retains" an equipment reversion outside the lease and therefore must assign it separately from rights arising under the lease. ${ }^{36}$ To the extent that this "metaphysical" 37 approach has a basis in the Code, it presumably must rely on the distinction between true and security leases drawn in $\S 1-201(37){ }^{38}$ However, nothing in $\S 1-201(37)$ suggests that the distinction should lead to differing treatment of leasehold assignments. In any event, $\$ 1-201(37)$ does not support the notion that a security lessor parts with title to the equipment and then takes back a security interest. The second sentence of the section states, "The retention or reservation of title by a seller of goods . . . is limited in effect to a reservation of a security interest." 39 The security lease is a "title retention device" whereby the security lessor sells goods but reserves title as collateral for the lessee's payments. ${ }^{40}$ Therefore, the security lessor reserves a security interest just as the true lessor reserves an equipment reversion. If reservation of an interest were the key, a double perfection rule would also have to be used for assignments of security leases and other title retention devices such as conditional sales contracts. ${ }^{41}$

The alternative approach is to begin with what Article 9 defines, in $\S 9-105(1)(b)$, as "chattel paper": "a writing or writings which evidence both a monetary obligation and a security interest in or a lease of specific goods." As Levie noted, ${ }^{42}$ both security leases ("a monetary obligation and a security interest") and true leases ("a monetary

\section{See p. 1726 supra.}

37. Clark, supra note 14 , at 237.

38. Another possible source of authority for a double perfection rule cited by the Leasing Consultants courts is the Comment to $\$ 9-101$ which states that "for some purposes, there are distinctions based on the type of property which constitutes the collateral ...."See 351 F. Supp. at 1392; 486 F.2d at 370 . There is no reason to think that this Comment was meant to approve distinctions betwcen assignments of different types of leasehold interests. See the excerpts from the same Comment at pp. 1730-31 infra. Both true and security leases are Article 9 chattel paper, pp. 1728-29 infra; in Comment 5 to $\$ 9.102$ and the tables which follow, chattel paper, not a subdivision thereof, is referred to as one of the "particular types of collateral" to which "special rules" apply.

39. (Emphasis added.)

40. See I GILMORE, supra note $7, \$ 3.2$, at $67, \$ 3.6$, at 76-77.

41. See also $\$ 9.202$ : "Each provision of this Article with regard to rights, obligations and remedies applies whether title to collateral is in the secured party or in the debtor."

42. Levie, supra note 26 , at 939. 
obligation and ... a lease") are chattel paper when assigned.43 The assignee's security interest in chattel paper can be perfected either by possessing the paper or by filing against it. ${ }^{44}$ The issue of what perfection rule should apply to each type of leasehold assignment becomes a question of the rights which can be perfected through chattel paper.

A single perfection rule for security lease assignments follows directly from the chattel paper definition. Security lease-chattel paper evidences both the obligation of the lessee to make rental payments to his lessor and the lessor's security interest in the leased goods. Perfection by the lessor's assignee of a security interest in the paper perfects the assignee's interest in both of the underlying obligations. ${ }^{45}$

For true lease assignments, the true lessor's right to receive rental payments from the lessee is once again the $\$ 9-105$ "monetary obligation," but the meaning of "lease" in $\$ 9-105$ is not clear. Three alternatives seem possible. First, "lease" could be construed as the rental payments which the lessee owes to the lessor. Since the rental payments are already included in the chattel paper by the reference to "monetary obligation," however, the word "lease" would become redundant to the extent that it would not add to the interests perfectible through true-lease chattel paper.46 By contrast, both the "monetary obligation" and the "security interest" in security lease-chattel paper refer to interests which are perfectible through the chattel paper. A second interpre-

43. "[W]hether or not the lease itself is a security agreement, it is chattel paper when transferred if it relates to specific goods." $\$ 9-105$, Comment 3 .

True leases, security leases, and other security agreements can be termed chattel paper only when they are assigned. See, e.g., \$ 9-105, Comment 4:

A dealer sells a tractor to a farmer on conditional sales contract or purchase money security interest. The conditional sales contract is a "security agreement," the farmer is the "debtor," the dealer is the "secured party" and the tractor is the type of "collateral" defined in Section 9-109 as "equipment." But now the dealer transfers the contract to his bank, either by outright sale or to secure a loan. Since the conditional sales contract is a security agreement relating to specific equipment, the conditional sales contract is now the type of collateral called "chattel paper." In this transaction between the dealer and his bank, the bank is the "secured party," the dealer is the "debtor," and the farmer is the "account debtor." (Emphasis added.) See also \$9.302(2), Comment 7 .

If a security lease were chattel paper in the hands of a lessor, the lessor could perfect an interest against the lessee merely by holding the security lease-chattel paper. See below. The Code, however, requires a security Iessor to filc its interest. See pp. 1723-24 supra. Similarly, if the true lessor were deemed to hold chattel paper against the lessee, the lessor would have to perfect its security interest under the rules governing chattel paper. But the true lessor docs not have to takc any action to perfect its interest. See p. 1725 supra.

44. $\$ \$ 9.304(1),-305$.

45. Courts and commentators have never questioned the Second Circuit's view that the Code requires a single perfection rule for security lease assignments. See p. 1726 supra; Clark, supra note 14, at 238-39; Levie, supra note 26, at 940.

46. Under this interpretation, the word "lease" would still serve to include true leases in chattel paper. See $\S 9-105$, Comment 4 . Therefore, it would not strictly speaking become surplusage. 
tation of "lease," as the ancillary obligations between true lessors and lessees (for example, the obligation of either party to keep the equipment in good repair), would be likewise redundant. The Comment to $\$ 9-106$ makes clear that such obligations are included in the rights to payment under all types of chattel paper.47

A third chattel paper definition avoids the redundancy problem. The word "lease" could be construed to mean the equipment reversionthe right to repossess the equipment on default or expiration of the lease. ${ }^{48}$ The "lease" in true lease-chattel paper, like the "security interest" in security lease-chattel paper, would add to the rental payments another interest perfectible through chattel paper. A single perfection rule for true lease assignments would then follow; perfection of a security interest in true lease-chattel paper would perfect an interest both in the rental payments and in the equipment reversion..$^{49}$

The Code does not compel either a single or double perfection rule for true lease assignments. Since the drafters of the Code did not specifically work through the true lease assignment problem, ${ }^{, 0}$ any argument for a single perfection rule must be indirect and inferential. ${ }^{51}$ However, $\$ 1-201(37)$ does not support the Second Circuit's theory for double perfection, and the definition of chattel paper seems to suggest single perfection.

\section{The Article 9 Policy of Uniformity}

Both the district court and the Second Circuit in Leasing Consultants noted with approval the Comment to $\$ 9$-101, which states the purpose of Article 9:

47. "Whatever perfection is required for the perfection of an assignment of the right to the payment of money will also carry these ancillary rights."

48. Another approach which avoids the redundancy problem would be to construe "lease" to mean an interest in the equipment to the extent of any unpaid rentals. However, this "hybrid" approach should be rejected. See note 33 supra.

49. The perfection of a security interest must be distinguished from its creation by contract between lessor and assignee; both are needed for a perfected security interest. The fact that it is possible to perfect a security interest in an equipment resersion through a true lease does not mean that whenever a lessor assigns a "lease," the lessor has assigned a security interest in the reversion as well as in the rental payments. Whether the assignment includes both interests would be a question of contract law.

50. See pp. 1722-23 supra.

51. See also $\$ 9-102(3)$ :

The application of this Article to a security interest in a secured obligation is not affected by the fact that the obligation is... secured by a transaction . . . to which this Article does not apply.

In other words, Article 9 applies to a "secured obligation" between a lessor and his assignee whether or not the Code requires the lessor to file against the lessee. 1 GlLMorr, supra note $7, \S 10.6$, at 312 n.3. 
[T]o provide a simple and unified structure within which the immense variety of present day secured financing transactions can go forward with less cost and greater certainty.

The scheme of this Article is to make distinctions, where distinctions are necessary, along functional rather than formal lines. ${ }^{52}$

The policy of uniformity underlying Article 9 requires a clear functional, rather than formal, distinction between assignments of true and security leases to justify the application of differing perfection rules.

While Leasing Consultants seems to be the first case in which the distinction has been raised in a contest between the lessor's trustee in bankruptcy and the lessor's assignee, the distinction has a long history in contests between the lessee's trustee in bankruptcy and the lessor. ${ }^{53}$ Courts developed the distinction to preserve the integrity of pre-Code secured transactions filing statutes. In an effort to avoid the filing: requirements and the related limitations on the rights of creditors, 19th-century lawyers began to put purchase money security transactions in the form of leases, which were not explicitly covered by the statutes. Courts responded to these attempts at evasion by distinguishing between true leases and those which were merely "disguised" security agreements, and by holding the latter subject to the filing requirements. ${ }^{54}$

Whatever its current validity, ${ }^{55}$ this historical rationale for the dis-

52. 351 F. Supp. at 1392; 486 F.2d at 370. (The courts quoted the first of the two sentences but not the second.) See also $\$ 9-106$, Comment: "[I]t is not the intent of the Code to split up the rights to the payment of money and its ancillary supports, and thereby multiply the problem of perfection of assignments."

53. The Leasing Consultants courts cited three cases dealing with the true leascsecurity lease distinction. Allen v. Cohen, 310 F.2d 312 (2d Cir. 1962), cited at 351 F. Supp. at 1392; In re Telemax Corp., 10 UCC Rep. Serv. 1316 (S.D.N.Y. 1971) (Babbit, Ref.), cited at 486 F.2d at 373 ; In re Walter Willis, Inc., 313 F. Supp. 1274 (N.D. Ohio 1970), aff'd, $440 \mathrm{~F} .2 \mathrm{~d} 995$ (6th Cir. 1971), cited at $486 \mathrm{~F} .2 \mathrm{~d}$ at 373 . In all three cases, the party arguing for the distinction was the lessee's trustee in bankruptcy. See also cases cited in White \& Summers, supra note 8, $\$ 22-3$, at 760 n.3 (various third parties successfully attacking security lessor's unperfected interest).

54. 1 GILMoRE, supra note $7, \$ 3.6$, at 76-77; see Coogan, supra note 5, at 936-38; Levin, supra note 17, at 135-37. In applying the distinction, courts generally went no further than necessary to protect the purposes of the filing statutes. For example, long term leases of equipment commonly known to be on lease, such as shoe machinery and computers, often contained contract terms similar to those found in security leases. Nevertheless, courts refused to treat these long term leases as security leases because "no creditor could rationally claim to have been misled by the presence of an I.B.M. machine or a telephone on his debtor's premises." I GiLMORE, supra note 7 , $\$ 3.6$, at 79 .

55. Both true and security leases are now used primarily to finance the acquisition of equipment. See Hiller, Security Aspects of Chattel Leases in Bankruptc); 34 FordHAM L. REv. 439 (1966); Riordan \& Duffy, supra note 6, at 763-64; Weiss \& McGugan, supra note 6 , at 3; Comment, supra note 9 , at 134-35. The similarity in the economic function of true and security leases has led some commentators to contend that the distinction 
tinction does not justify different filing requirements for true and security lease assignees to perfect against the lessor's trustee in bankruptcy. ${ }^{56}$ The lessor's trustee in bankruptcy represents the lessor's creditors, whose concern is whether the lessor has already granted an interest in the lease to a prior secured party. The nature of the underlying lease agreement has no bearing on this concern. The filings necessary to give adequate notice to the lessor's buyers and creditors do not depend on the terms of the lease. The distinction may in fact mislead creditors of the lessor who take a security interest in leased equipment believing that the agreement is a true lease and relying on the absence of an equipment filing. ${ }^{57}$ Indeed, in the very article which provided the primary authority for the Leasing Consultants double perfection rule, the author expressed the view that the "differences in treatment [of true and security lease assignees] create distortions in the second level chattel paper transaction without any rational justification." 58

Assuming that the same perfection rule should apply to both true and security lease assignments, the question becomes which rule to apply. The double perfection rule imposes additional filing costs on assignees ${ }^{59}$ without substantially improving the notice to the buyers and creditors of the lessor; ${ }^{60}$ on balance the single perfection rule

should be abolished. Levie, supra note 26, at 941; Comment, supra note 9, at 136-37; cf. GILMORE, supra note 7, $\$ 3.6$, at 81 . But see Coogan, supra note 5 , at 960.61. This Note need not go so far; it contends only that there is no justification for the distinction at the assignment step.

56. If a security lessor has filed, the Code does not require the assignee to file in order to perfect against the lessee's trustee in bankruptcy. $\$ 9$-302(2).

57. The line between true and security leases is unclear, see Coogan, supra note 5 , at 911 ; if the agreement were subsequently shown to be a security lease (e.g., by parole evidence not available to the creditor, see 486 F.2d at 373), the creditor could be defeated by a prior assignee of the lessor who had perfected an interest in the equipment under the single perfection rule applicable to security leases, see $\$ 9-312(5)$, and possibly even by a subsequent assignee. Cf. Clark, Abstract Rights versus Paper Rights under Article 9 of the Uniform Commercial Code, 84 YALE L.J. 445, 463-64 (1975).

58. Levie, supra note 26 , at 939 .

59. If the lessor, leases and assignee are all in the same state, the costs imposed by the extra filings against the equipment will be minimal. A greater, but probably not excessive, inconvenience results if the lessor is operating in several states but has only one security assignee. In that case, the assignee need make only one general filing in each state. The leased goods are "inventory" of the lessor and the Code permits perfection of security interests in inventory by means of a general filing. $\$$ 9-109(4); see, e.g., In re Varney Wood Prod., 485 F.2d 435, 437 (4th Cir. 1972). However, the extra filings put a heavy burden on the large multistate lessor with a number of security assignees. A lessor's assignee who was allowed to make a general filing against the lessor's equipment could later take priority over another assignee who actually received his security interest before, but only filed after, the first assignee. See $\$ 9-312(5)$. Since the possibility of such a result would be unacceptable to subsequent assignees, the lessor would have to require the filings of each assignee to specify precisely the equipment covered. As new leases replaced old ones in the assignees' portfolios, the cost of the filings and refilings and the risk of critical clerical errors would increase.

60. The district court in Leasing Consultants reasoned that the equipment filings required by a double perfection rule were necessary to protect third party creditors of 
seems preferable. ${ }^{61}$ As a practical matter, regardless of the perfection rule adopted, parties dealing with the lessor may continue to file ${ }^{62}$ and to search ${ }^{63}$ at the location of both the lessor ${ }^{64}$ and the equipment. It is not necessary, however, to resolve the complexities of double and single perfection in order to reject the Second Circuit's double perfection rule for true lease assignments. Given a Code policy of uniformity and an established single perfection rule for security leases, ${ }^{65}$ the same rule should apply to true leases.

the lessor. The court cited the possibility that, under a single perfection rule, a judgment creditor might rely on the absence of a filing at the situs of the equipment, and attach the equipment in which the financing assignee had already perfected a security interest through the lease. 351 F. Supp. at 1393-94, cited without comment, 486 F.2d at $37 \mathrm{I} \mathrm{n.4.} \mathrm{If} \mathrm{a} \mathrm{single} \mathrm{perfection} \mathrm{rule} \mathrm{were} \mathrm{established} \mathrm{for} \mathrm{true} \mathrm{lease} \mathrm{assignments,} \mathrm{how-}$ ever, the creditor would not rely upon the absence of an equipment filing, any more than if the underlying agreements were security leases. The creditor would be aware of the need to check for a perfected interest in the equipment through the chattel paper. See Clark, supra note 14, at 238-39.

61. The 1972 version of the Code gives a single perfection rule at least one further advantage over double perfection. Under a double perfection rule, the party who searches for other perfected security interests in the equipment will check for filings at the situs of the equipment ( $\$ 9-102(1)$; WhITE \& Summers, supra note $8, \$ 23-18$, at 847); under a single perfection rule, at the situs of the lease ( $\$ 9-102(1)$ (1962 version)) or of the chief executive office of the lessor ( $\$ 9-103$ (1972 version)). The searching party must also check to see that the equipment, lease or lessor has not moved from one state to another within four months. See $\S 9-103(3)$. The lessor is less likely to move its chief executive office than its leased equipment; accordingly, under the 1972 version, the single perfection rule makes for an easier search process than a double perfection rule. (By the same reasoning, if equipment is moved less frequently than leases, the 1962 version would make the search easier under double perfection than single perfection.)

62. This filing is necessary to give the assignee priority in equipment repossessed by the lessor after default or expiration of the lease. See Clark, supra note 14, at 234 \&. n.14.

63. A perfected security interest in the equipment granted before the current lease began would be superior to an interest in the cquipment perfected subsequently through the lease under a single perfection rule. See Clark, supra note 57, at 464 . An assignce who had failed to check for such filings could lose to the prior secured party.

64. Under the 1962 version of the Code, the searching party would check at the location of the leases, rather than at the lessor's chief executive office. See note 61 supra.

65. P. 1729 supra. 